\title{
ANALISIS AKUNTABILITAS, TRANSPARANSI DAN EFEKTIVITAS PENGELOLAAN DANA BANTUAN OPERASIONAL SEKOLAH (BOS) (STUDI KASUS PADA SMP NEGERI 3 DAN SMP ISLAM YPUI DARUL ULUM DI KOTA BANDA ACEH)
}

\author{
Faisyal Ammar*1, Bustamam ${ }^{* 2}$ \\ ${ }^{1,2}$ Program Studi Akuntansi Fakultas Ekonomi dan Bisnis Universitas Syiah Kuala \\ e-mail: faisyalammar@gmail.com ${ }^{* 1}$, bustamam@ unsyiah.ac.id $^{* 2}$
}

\begin{abstract}
Abstrak
The purpose of this study was to determine the implementation of accountability, transparency, and effectiveness in managing the School Operational Assistance (BOS) funds in public and private Junior High School in Banda Aceh City. This research involved two objects, Junior High School 3 Banda Aceh and Islamic Junior High School YPUI Darul Ulum. This research used the qualitative descriptive method and also used primary and secondary data in data collection. The primary data were obtained directly by interviewing informants that were BOS coordinator in Education and Culture Services of Banda Aceh City and school BOS team consisting of the school principal and BOS treasure. The data were collected by direct observation in the field. The secondary data were collected by using documentation technique. In analyzing the data, the researcher used data reduction, data presentation, and data verification. The result of the study showed that the accountability, transparency, and effectiveness in managing the School Operational Assistance (BOS) funds in Junior High School 3 Banda Aceh were in accordance with the Regulation of the Minister of Education and Culture (Permendikbud) No. 26 of 2017 which reflected good governance, while the management of the School Operational Assistance (BOS) funds in Islamic Junior High School YPUI Darul Ulum Banda Aceh in terms of transparency was still not perfect, but in terms of accountability and effectiveness were in accordance with the Regulation of the Minister of Education and Culture (Permendikbud) No. 26 of 2017.
\end{abstract}

Keywords: Accountability, Transparency, Effectiveness, School Operational Assistance (BOS) funds

\section{Pendahuluan}

Indonesia merupakan salah satu bangsa yang memikirkan kualitas pendidikannya. Sesuai dengan isi pembukaan Undang-Undang Dasar (UUD) Negara Republik Indonesia tahun 1945 pada alinea ke empat menyebutkan bahwa mencerdaskan kehidupan bangsa sebagai salah satu tujuan bangsa Indonesia. Isi UUD tersebut mengandung makna yang sangat besar, bahwa bangsa Indonesia harus memperhatikan pendidikan untuk warganya dan tidak hanya memperhatikan serta mengangkat derajat sosial ekonomi warganya saja, namun bangsa Indonesia mempunyai tugas untuk menumbuhkan warganya menjadi seseorang yang berguna bagi kehidupannya sendiri, sosial dan untuk bangsa Indonesia.
Berdasarkan UUD 1945 pada Pasal 31 ayat (1) dan (2) menegaskan bahwa warga negara Indonesia berhak mendapatkan pendidikan dan pemerintah wajib membiayainya, kemudian pemerintah juga mengatur mengenai bagaimana sistem pendidikan yang ada di Indonesia dalam UU Nomor 20 Tahun 2003 Tentang Sistem Pendidikan Nasional, yang isinya menegaskan bahwa setiap warga Negara Indoensia berhak mendapatkan pendidikan tanpa batas. Pemerintah harus menyadari bahwa pendidikan merupakan suatu investasi bagi bangsa Indonesia, karena dengan adanya pendidikan dengan kualitas yang baik dapat meningkatkan perekonomian Indonesia dan ini juga merupakan salah satu upaya dalam memberantas kemiskinan dalam program pembangunan nasional. 
Upaya pemerintah untuk mewujudkan pembangunan nasioanal dalam memberantas kemiskanan dan meningkatkan mutu pendidikan, pemerintah merancang program wajib belajar 9 tahun. Salah satu cara mewujudkan pelaksanaan program tersebut, pemerintah merancang program penyediaan pendanaan untuk membiayai kegiatan nonpersonalia yang dapat digunakan sekolah untuk mengurangi biaya yang akan dibayar. Program ini disebut sebagai dana Bantuan Operasional Sekolah (BOS), program ini yang menjadi target untuk kelancaran program wajib belajar 9 tahun pada tingkat dasar dan menengah pertama.

Program dana BOS diharapkan selalu efektif dalam implementasinya, tanpa dana ini sekolah tidak akan berjalan secara baik. Dalam kesehariannya sekolah membutuhkan dana untuk biaya-biaya operasionalnya, karena biaya ini merupakan hal yang paling penting dalam pendidikan. Program BOS ini juga yang meringankan masyarakat dalam biaya pendidikan, sesuai dengan salah satu tujuannya membebaskan masyarakat yang tergolong tidak mampu dari semua pungutan. Jadi seharusnya tidak ada lagi masyarakat miskin yang tidak dapat mengikuti pendidikan yang layak.

Penyaluran dana BOS haruslah mengikuti regulasi yang telah ditetapkan pemerintah, untuk tahun 2018 ini pemerintah telah mengeluarkan Peraturan Menteri Pendidikan dan Kebudayaan Republik Indoensia atau yang disingkat dengan Permendikbud Nomor 1 Tahun 2018 Tentang Petunjuk Teknis Bantuan Operasional Sekolah terbaru yang disahkan januari lalu, regulasi ini di singkat dengan kata Juknis BOS, untuk regulasi ini pemerintah selalu melakukan pembaharuan setiap tahunnya. Hamid Muhammad mengatakan terdapat penyimpangan dana BOS yang diakibatkan karena adanya penyimpangan regulasi yang terjadi. Pelanggaran ini dilakukan oleh penerima dana BOS (CNN Indonesia, 21 Mei 2016). Berdasarkan kasus ini bisa disimpulkan bahwa regulasi yang telah dibuat dengan sebaik-baiknya masih saja bisa dilanggar tanpa adanya rasa bersalah.

Berdasarkan Permendikbud Nomor 26 Tahun 2017 Tentang Petunjuk Teknis Bantuan Operasional Sekolah menyebutkan dalam pengelolaan dana BOS menggunakan sistem Manajemen Berbasis Sekolah atau disingkat MBS, dalam menjalankan sistem ini memiliki beberapa kriteria yang harus dipenuh. Salah satu ketentuan pada pengelolaan dana BOS yang menggunakan sistem MBS haruslah menerapkan prinsip efesien, efektif, akuntabel, dan transparansi. Tujuan dari regulasi ini guna mencapai pengelolaan dana BOS menjadi tepat sasaran dan meminimalkan tingkat penyimpangan dan penyelewengan.

Setiap tahun pemerintah terus memperbarui Juknis dalam pengelolaan dana BOS, agar pengelolaan dana BOS terus meningkat menjadi lebih baik dan mengurangi angka penyimpangan. Namun dalam kenyataan yang terjadi meskipun regulasi setiap tahun terus diperbaharui masih saja terdapat penyimpangan yang terjadi. Pada penelitian sebelumnya yang berjudul "Evaluasi Pengelolaan Dana Bantuan Operasional Sekolah (BOS)" mengatakan bahwa pelasksanaan dana BOS yang terjadi masih belum sejalan dengan aturan yang tertera pada Juknis BOS 2015 tepatnya dalam segi penyusunannya dan masalah lain pada proses pencairan yang mengalami keterlambatan . Penggunaan dalam dana BOS juga belum sesuai dengan aturan yang ada pada Juknis BOS 2015 yang berlaku dan yang terakhir tentang pelaporan yang belum sesuai karena tidak adanya transparansi (Silele et al., 2017).

Penyimpangan lain yang terjadi pada pengelolaan dana BOS, jika ditelusuri dalam media berita kita bisa menemukan beberapa permasalahan yang tejadi terkait pengelolaan dana BOS. Kejadian lain yang diberitakan oleh media di Cianjur menyebutkan bahwa terjadinya penyimpangan yang bersifat administrasi (Beritacianjur, 8 Januari 2018). Selain penyimpangan dengan masalah regulasi atau admnistrasi masih ada penyimpangan lainnya yang dapat menghambat dana BOS.

Salah satu masalah selain penyimpangan adalah keterlambatan penyaluran dana BOS, seperti yang terjadi di Aceh keterlambatan penyaluran dana BOS sampai minggu keempat Februari oleh pemerintah pusat sedangkan daerah lainnya sudah menerimanya (Serambinews, 26 Februari 2018). Kasus lainnya, ratusan kepala sekolah di Jawa Timur harus mengeluarkan uang pribadinya untuk biaya operasi sekolah dikarenakan dana BOS juga belum cair (Jpnn, 21 Februari 2018). Berdasarkan beberapa kasus ini bisa disimpulkan bahwa masalah seperti ini 
menurunkan tingkat kepercayaan masyarakat dan hal ini akan berdampak tidak baik.

Objek dalam penelitian ini yang dipilih oleh peneliti yaitu SMP Negeri dan Swasta di wilayah Kota Banda Aceh. Alasan peneliti memilih objek pada SMP karena pada jenjang menengah pertama ini kegiatan sekolah lebih aktif daripada SD, dimana pada jenjang ini sudah ada OSIS (Organisasi Siswa Intra Sekolah), yang pastinya dana BOS terlibat dalam kegiatan ini dan juga SMP masih dibawah tanggungjawab Dinas Pendidikan Kota Banda Aceh. Dengan demikian peneliti tertarik untuk meneliti SMP Negeri 3 Banda Aceh dan SMP Islam YPUI Darul Ulum Banda Aceh, dengan alasan karena kedua sekolah ini memiliki nilai akreditasi tertinggi yaitu dengan nilai A diantara sekolah negeri dan swasta lainnya.

Atas dasar beberapa fenomena diatas, peneliti tertarik menyusun penulisan skripsi dengan judul "Analisis Akuntabilitas, Transparansi dan Efektivitas Pengelolaan Dana Bantuan Operasional Sekolah (BOS) (Studi Kasus pada SMP Negeri 3 dan SMP Islam YPUI Darul Ulum di Kota Banda Aceh)".

Berdasarkan uraian penjelasan tentang dana Bantuan Operasional Sekolah diatas, maka peneliti dapat merumuskan masalah bagaimana pengelolaan dana BOS dari segi akuntabilitas pada SMP Negeri 3 \& SMP Islam YPUI Darul Ulum di Kota Banda Aceh, bagaimana pengelolaan dana BOS dari segi transparansi pada SMP Negeri 3 \& SMP Islam YPUI Darul Ulum di Kota Banda Aceh dan bagaimana pengelolaan dana BOS dari segi efektivitasnya pada SMP Negeri 3 \& SMP Islam YPUI Darul Ulum di Kota Banda Aceh.

Adapun tujuan yang diharapkan oleh peneliti untuk mengetahui bagaimana pengelolaan dana BOS dari segi akuntabilitas pada SMP Negeri 3 \& SMP Islam YPUI Darul Ulum di Kota Banda Aceh, untuk mengetahui bagaimana pengelolaan dana BOS dari segi transparansi pada SMP Negeri 3 \& SMP Islam YPUI Darul Ulum di Kota Banda Aceh dan untuk mengetahui bagaimana pengelolaan dana BOS dari segi efektivitasnya pada SMP Negeri 3 \& SMP Islam YPUI Darul Ulum di Kota Banda Aceh.

Hasil dari penelitian ini diharapkan dapat memberikan konstribusi dalam menambah ilmu pengetahuan, terutama dalam bidang pengelolaan dana Bantuan Operasional Sekolah baik itu bagi penulis sendiri dan bagi pembaca. Selain itu, penelitian ini diharapkan sebagai langkah perubahan dalam pendidikan di Indonesia ke langkah yang lebih baik yang dilihat dari hasil penelitian ini. Selain itu, Untuk mengetahui bagaimana kesesuaian dalam pengelolaan dana Bantuan Operasional Sekolah (BOS) dengan Permendikbud Nomor 26 Tahun 2017 dari segi akuntabilitas, transparansi dan efektivitasnya. Selain itu juga dapat menjadi suatu bahan evaluasi bagi pengelolaan dana BOS agar pengelolaan dana BOS dapat ditingkatkan lagi dan dilakukanya perbaikan terhadap masalah yang ada.

\section{Tinjauan Pustaka}

Akuntansi Sektor publik

Akuntansi merupakan proses pencatatan dan melaporkan informasi ekonomi, akuntansi tidak hanya dipakai dalam dunia bisnis tetapi juga dalam pemerintahan juga. Akutansi sektor publik merupakan mekanisme tata cara penggunaan akuntansi pada semua lembaga-lembaga negara dan pihak lainnya yang terlibat dengan pemerintah, sesuai dengan (Bastian, 2014:2). Dalam Undang-Undang Republik Indonesia juga mengatur bagaimana organisasi nirlaba menggunakan sistem akuntansi sektor publik, seperti yang dijelaskan pada pasal 3 ayat (1) Undang-Undang Republik Indonesia Nomor 17 Tahun 2003 menjelaskan bahwa pengelolaan keuangan negara harus dikelola secara tertib, taat pada peraturan perundang-undangan, efisien, ekonomis, efektif, transparan, dan bertanggung jawab dengan memperhatikan rasa keadilan dan kepatutan.

\section{Pengelolaan Keuangan}

Pengelolaan keuangan atau bisa disebut juga manajamen keuangan merupakan kegiatan dalam mengatur jalannya keuangan untuk mencapai tujuan yang telah direncanakan, sesuai dengan Soetjipto (1992:76) dalam Fitri (2014) menjelaskan bahwa pengelolaan keuangan meliputi: kegiatan perencanaan, penggunaan atau pemanfaatan, pencatatan data, pelaporan dan pertanggungjawaban yang dialokasikan untuk menyelenggarakan sekolah dengan tujuan untuk menunjukkan tertib adminstrasi keuangan sehingga pengurusannya dapat dipertanggungjawabkan sesuai dengan ketentuan yang berlaku. Pada pengelolaan dana BOS yang diberikan kepada sekolah juga harus 
dikelola dengan baik agar mencapai tujuan yang telah direncanakan.

\section{Definisi Dana Bantuan Operasional Sekolah (BOS)}

Silele et al., (2017) mengatakan bahwa dana BOS merupakan program pemerintah untuk mebiayai kegiatan nonpersonalia sekolah untuk mewujudkan program wajib belajar. Menurut Peraturan Menteri Pendidikan Nasional Nomor 69 Tahun 2009 tentang Standar Biaya Operasi Nonpersonalia pada pasal 1 menjelaskan bahwa standar biaya operasi nonpersonalia adalah standar biaya yang diperlukan selama 1 (satu) tahun periode yang bertujuan agar satuan pendidikan dapat berjalan dengan teraratur dan berkelanjutan sesuai dengan aturan standar pendidikan nasional. BOS menjadi hal yang sangat penting dalam kegiatan operasi sekolah dan dalam kehidupan masyarakat karena dapat mengurangi beban masyarakat.

\section{Permendikbud Nomor 26 Tahun 2017}

Permendikbud Nomor 26 Tahun 2017 adalah peraturan yang dibuat oleh kementrian pendidikan dan kebudayaan tentang petunjuk teknis dalam penggunaan atau pengelolaan dana BOS. Dalam petunjuk teknis ini tertera bagaimana regulasi yang harus ditaati oleh pengguna dana BOS dan semua teknis dalam pengelolaan dana BOS ada didalam petunjuk teknis yang harus diikuti oleh pengguna dana BOS.

Peraturan ini dibuat oleh pemerintah agar tujuan dari dana BOS tercapai secara maksimal dan menguranginya penyelewengan atau masalah lainnya. Petunjuk teknis dana BOS setiap tahunnya dilakukan pembaharuan dengan tujuan memberikan hasil yang lebih baik dari tahun sebelumnya agar tercapainya tujuan yang direncanakan sejak awal.

\section{Pengelolaan Dana Bantuan Operasional Sekolah (BOS)}

Pengelolaan merupakan suatu usaha untuk mengatur agar mencapai tujuan, begitu pula dengan pengelolaan dana BOS. Menurut Anggraini (2013), pengeloaan merupakan suatu serangkaian kegiatan untuk mencapai tujuan. Berdasarkan pengertian pengelolaan dapat disimpulkan bahwa pengelolaan dana BOS merupakan serangkaian kegiatan untuk mengwujudkan program pemerintah wajib belajar 9 tahun dalam hal biaya pendidikan. Dalam Permendikbud Nomor 26 Tahun 2017 juga menegaskan bahwa pengelolaan dana BOS menggunakan prinsip manajemen berbasis sekolah (MBS) agar program dana BOS ini berjalan dengan efektif dan efesien.

\section{Manajemen Berbasis Sekolah (MBS)}

MBS merupakan suatu sistem yang digunakan oleh sekolah untuk mengelola sekolahnya agar tercapainya tujuan sekolah. Menurut Undang-Undang Republik Indonesia Nomor 20 Tahun 2003 tentang Sistem Pendidikan Nasional pada pasal 51 ayat (1), menjelaskan bahwa pengelolaan pendidikan pada tiga tingkat yaitu usia dini, tingkat dasar dan menengah harus berdasarkan standar dengan prinsip manajemen berbasis sekolah. Pratiwi (2016) menjelaskan bahwa manajemen berbasis sekolah merupakan pemberian wewenang kepada pihak yang terlibat langsung dengan sekolah untuk mengatur pengelolaan sekolahnya sendiri yang bertujuan untuk memajukan sekolah. Model MBS yang baik adalah MBS yang terstruktur dalam suatu konsep sistem yang efektif dan efesien untuk mencapai tujuan pendidikan yang produktif (Ismail, 2008).

\section{Tujuan Dana Bantuan Operasional Sekolah (BOS)}

Menurut Andi et al., (2015), menjelaskan bahwa program dana BOS memiliki tujuan untuk dapat mebiayai biaya pendidikan guna meringankan beban masyarakat. Berdasarkan Permendikbud Nomor 26 Tahun 2017 juga menjelaskan bahwa tujuan dana BOS pada jenjang SD/SDLB dan SMP/SMPLB. Kedua tingkat ini memiliki tujuan yang sama yaitu:

1) Meringankan pendanaan dalam biaya operasi nonpersonalia, akan tetapi masih ada pendanaan untuk biaya personalia dari dana BOS;

2) Menghilangkan pemungutan biaya operasi sekolah bagi peserta didik;

3) Meminimalkan beban biaya sekolah bagi peserta didik; dan/atau

4) Menghilangkan pungutan kepada pesesta didik yang orang tua/walinya tergolong kurang mampu. 


\section{Sasaran, Satuan Biaya dan Waktu Penyaluran Dana Bantuan Operasional Sekolah (BOS)}

Berdasarkan Permendikbud Nomor 26 Tahun 2017 telah menjelaskan siapa saja yang menjadi sasaran untuk menerima dana BOS ini, target yang menjadi sasarannya yaitu SD/SDLB dan SMP/SMPLB, untuk satuan biaya yang didapatkan oleh masing-masing target juga berbeda tergantung kepada tingkat pendidikannya. Adapun perkembagan satuan biaya dari tahun 2016 dan 2017 yang diperoleh masing-masing tingkat pendidikan yaitu:

Tabel 2.1 Besaran Biaya

\begin{tabular}{|c|l|l|}
\hline \multicolumn{1}{|c|}{ Sekolah } & \multicolumn{1}{|c|}{2016} & \multicolumn{1}{|c|}{2017} \\
\hline SD/SDLB & $\begin{array}{l}\text { Rp. 580.000,- } \\
\text { /peserta } \\
\text { didik/tahun }\end{array}$ & $\begin{array}{l}\text { Rp. 800.000, - } \\
\text { /peserta } \\
\text { didik/tahun }\end{array}$ \\
\hline SMP/SMPLB & $\begin{array}{l}\text { Rp. 710.000, - } \\
\text { /peserta } \\
\text { didik/tahun }\end{array}$ & $\begin{array}{l}\text { Rp. 1.000.000, - } \\
\text { /peserta } \\
\text { didik/tahun }\end{array}$ \\
\hline
\end{tabular}

Sumber Data (Juknis BOS 2016 \& 2017)

Waktu penyaluran untuk mengalokasikan dana BOS yang tertera pada Permendikbud Nomor 26 Tahun 2017 yaitu setiap 3 (tiga) bulan sekali atau pertriwulan dalam satu tahun, tetapi untuk sekolah yang wilayahnya sulit untuk dijangkau diberikan aturan khusus sendiri yaitu penyaluran dananya setiap 6 bulan sekali atau setiap semester dalam 1 (satu) tahun. Presentase penyaluran dana BOS sebagai berikut:

1) Penyaluran tiap triwulan
a) Triwulan I :20\% dari alokasi satu tahun;
b) Triwulan II :40\% dari alokasi satu tahun;
c) Triwulan III :20\% dari alokasi satu tahun;
d) Trwiulan IV :20\% dari alokasi satu tahun.

2) Penyaluran tiap semester
a) Semester I :60\% dari alokasi satu tahun;
b) Semester II :40\% dari alokasi satu tahun.

Sekolah harus memenuhi ketentuan dalam penerimaan dana BOS yang ada pada Permendikbud Nomor 26 Tahun 2017 yaitu dana BOS harus diterima secara utuh tanpa ada pemotongan dan diterima menggunakan rekening sekolah itu sendiri dan hanya bendahara BOS yang boleh mengambil dana BOS dengan persetujuan dari kepala sekolah.

\section{Penggunaan Dana Bantuan Operasional Sekolah (BOS)}

Penggunaan dana BOS haruslah sesuai dengan regulasi yang ada dan tidak menyalahi aturan agar tercapainya tujuan BOS tanpa ada penyelewengan. Ketentuan dalam menggunakan dana BOS yang tertera pada Permendikbud Nomor 26 Tahun 2017 sebagai berikut:

1) Penggunaan dana BOS di sekolah harus didasari dengan kesepakatan dan keputusan bersama pada semua pihak yang terlibat, hasil kesepakatan dalam rapat harus dituangkan secara tertulis dan semua peserta rapat harus menandatangani pernyataan sepakat. Penggunaan dana BOS harus dipertimbangkan dengan sebaik-baiknya sesuai kebutuhan.

2) Dana BOS diprioritaskan untuk pennggunaan dalam mebiaya kegiatan operasional.

3) Honor untuk guru yang bekerja diluar jam kerjanya diberikan sesuai dengan satuan biaya yang ditetapkan oleh pemerintah daerah.

4) Bunga bank yang disebabkan oleh rekening BOS sudah diatur dalam peraturan perundangundangan.

\section{Pertanggungjawaban Keuangan Dana BOS}

Berdasarkan Permendikbud Nomor 26 Tahun 2017 perlunya pertanggungjawaban dalam penggunaan dana BOS. Pertanggungjawaban untuk para pengguna langsung dana BOS yaitu pihak sekolah harus membuat pembukuan secara lengkap sesuai dengan standar pengelolan pendidikan dan ketentuan peraturan perundang-undangan tentang penatausahaan dan pertanggungjawaban lembaga pengelola keuangan. Pembukuan yang dilakukan oleh pihak sekolah yaitu Rencana Kegiatatan dan Anggaran Sekolah (RKAS) merupakan rencana penggunaan dana BOS yang akan dilakukan oleh pihak sekolah, kemudian pembukuan yang lainnya yang harus dilakukan oleh pihak sekolah adalah pembukuan yang terkait dengan segala transaksi dalam pengunaan dana BOS.

Pertanggungjawaban lainnya yang harus dilakukan pihak sekolah yaitu pelaporan penggunaan dana BOS. Dalam pelaporan pihak sekolah harus melakukan beberapa jenis laporan yaitu laporan realisasi penggunaan dana tiap sumber dana, rekapitulasi realisasi penggunaan dana BOS, 
pencatatan pelayanan dan penanganan pengaduan masyarakat, laporan aset hasil dari penggunaan dana BOS, laporan ke Dinas Pendidikan dan yang terakhir adalah laporan online ke website BOS. Setelah pelaporan pihak sekolah harus melakukan transparansi dari penggunaan dana BOS, transparansi merupakan hal terakhir yang harus dilakukan oleh pihak sekolah untuk memenuhi aturan dalam pertanggungjawaban penggunaan dana BOS.

\section{Akuntabilitas}

Berdasarkan Permendikbud Nomor 26 Tahun 2017 pada bab pendahuluan juga menegaskan bahwa akuntabilitas termasuk dalam prinsip pengelolaan dana BOS. Dalam Peraturan Presiden Republik Indonesia Nomor 29 Tahun 2014 tentang Sistem Akuntabilitas Kinerja Instansi Pemerintah pasal 1 ayat (14) menjelaskan bahwa akuntabilitas kinerja merupakan kewajiban instansi pemerintah untuk mempertanggungjawaban atas kesuksesan atau kegagalan dari suatu kegiatan yang telah diamanatkan oleh pemangku kepentingan untuk mencapai target yang telah direncanakan. Beberapa penjelasan tentang akuntabilitas menjelaskan bahwa akuntabilitas adalah suatu kewajiban dalam pertanggungjawaban atas tindakan yang telah dilakukan dan hal ini yang membuat akuntabilitas sangatlah penting.

\section{Transparansi}

Transparansi sangat diperlukan oleh pemerintah dalam mengwujudkan good governance, oleh karena itu peneliti memilih transparansi sebagai penilaian dalam mengukur bagaimana tingkat keberhasilan pengelolaan dana BOS pada SMP Negeri dan Swasta. Menurut Kristianten (2006:73) menjelaskan bagaimana cara mengukur transparansi dengan beberapa indikator sebagai berikut:

1) Kesedian dan aksesibilitas dokumen.

2) Kejelasan dan kelengkapan informasi.

3) Keterbukaan proses.

4) Kerangka regulasi yang menjamin transparansi.

Indikator-indikator yang telah dijelaskan di atas, dapat membantu peneliti sebagai acuan bagaimana menilai keberhasilan dalam pengelolaan dana BOS yang dilakukan oleh pihak sekolah. Penilaian ini dapat dilihat bagaimana sikap sekolah dalam menyediakan dan akses informasi, kejelasan dana kelengkapan informasi, keterbukaan proses pengelolaan dana BOS dan bagaimana regulasi yang mengatur bagaimana transparansi dalam pengelolaan dana BOS yang dilakukan oleh pihak sekolah.

\section{Efektivitas}

Penelitian ini menggunakan efektivitas untuk mengetahui tingkat keberhasilan dalam pengelolaan dana BOS yang dilakukan oleh pihak sekolah. Efektivitas digolongkan berhasil dapat diukur dengan membandingkan tingkat perencanaan dan hasil, apakah hasil telah sesuai dengan perencanaan. Menurut Siagian (1978:77) mengkemukakan bagaimana kriteria efektivitas dan kriteria ini dapat menjadi acuan dalam penelitian ini dalam mengetahui bagaimana keberhasilan efektivitas dalam pengelolaan dana BOS, kriteria yang dikemukakan sebagai berikut:

1) Kejelasan dan tujuan yang hendak dicapai.

2) Kejelasan strategi pencapaian tujuan.

3) Proses analisis dan perumusan kebijakan yang sempurna.

4) Perencanaan yang tepat.

5) Penyusunan program yang tepat.

6) Tersedianya sarana dan prasarana kerja.

7) Pelaksanaan yang efektif dan efesien.

8) Sistem pengawasan dan pengendalian yang bersifat mendidik.

\section{Model Penelitian}

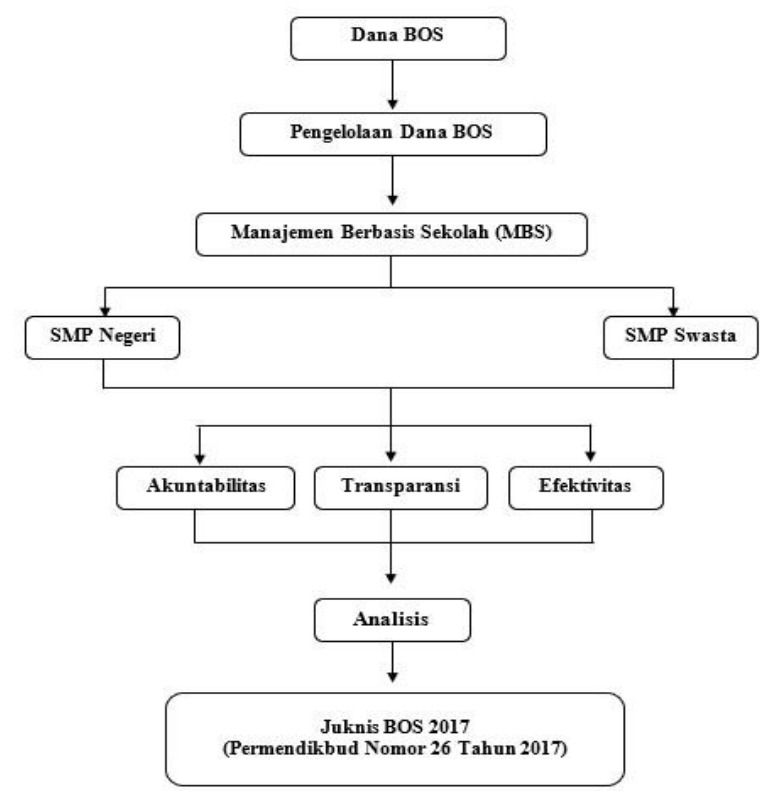

Gambar 2.1 Model Penelitian

Sumber: Data Diolah 2018 


\section{Metode Penelitian Desain Penelitian}

Proses penelitian ini menggunakan pendekatan kualitatif, data yang digunakan pada penelitian ini adalah data primer dan sekunder yang didapatkan langsung dilapangan yaitu dari wawancara, observasi langsung dan dokumen-dokumen resmi yang didapati dilapangan. Dalam penelitian ini peneliti bertujuan untuk memdeskripsikan mengenai kesesuaian pengelolaan dana BOS yang terdadi pada SMP Negeri 3 dan SMP Islam YPUI Darul Ulum di Kota Banda Aceh dengan Permendikbud Nomor 26 Tahun 2017 dalam segi akuntabilitas dan transparansi, kemudian peneliti juga ingin melihat bagaimana keefektifan dari pengelolaan dana BOS antara kedua SMP Negeri \& Swasta. Metode pengambilan data dalam penelitian ini menggunakan cross-sectional study atau one shoot, data yang diambil hanyak sekali. Sekaran \& Bougie (2016) menjelaskan cross-sectional merupakan penelitian dalam pengambilan datanya hanya satu kali dalam satu periode untuk menjawab pertanyaan penelitian.

\section{Objek dan Lokasi Penelitian}

Lokasi dalam penelitian ini dilakukan pada SMP Negeri 3 Banda Aceh dan SMP Islam YPUI Darul Ulum Banda Aceh.

\section{Teknik Pengumpulan Data}

Teknik pengambilan data dalam penelitian ini, yaitu dengan observasi, wawancara dan dokumentasi.

1) Observasi

Menurut Nasution (1988) dalam Sugiyono (2015:310) menyebutkan bahwa observasi merupakan dasar dari ilmu pengetahuan dengan adanyan observasi dapat menjelaskan data yang didapatkan langsung dilapangan.

2) Wawancara

Wawancara merupakan pertemuan antara dua orang untuk bertukar informasi melalui tanya jawab untuk mendapatkan kesimpulan dari topi yang menjadi permasalah (Esteberg, 2002) dalam (Sugiyono, 2015:317. Adapun sasaran yang menjadi informan dalam wawancara ini adalah pihak Dinas Pendidikan sebagai Tim BOS Kabupaten dalam pelaksanaan dana BOS dan TIM BOS pada sekolah yaitu kepala sekolah sebagai penanggungjawab pengelolaan dana BOS dam bendahara dana BOS sesuai dengan aturan yang tertera pada Permendikbud Nomor 26 Tahun 2017.

3) Dokumentasi

Menurut Sugiyono (2015:329) dokumen merupakan data informasi yang sudah berlalu, dokumentasi menjadi pelengkapan dari metode observasi dan wawancara. Penelitian ini menggunakan dokumentasi sebagai pelengkap informasi untuk membantu peneliti dalam memecah masalah yang sudah difokuskan. Dalam penelitian ini peneliti memerlukan beberapa dokumen dalam pengelolaan dana BOS yaitu pembukuan dan pelaporan.

\section{Teknik Analisis Data}

Teknik analisis data yang akan digunakan dalam penelitian ini menggunakan model yang dikemukan oleh Miles dan Huberman dalam sugiyono (2014:92-99). Model ini tediri dari 3 (tiga) tahapan dalam menganalisis data yaitu reduksi data, penyajian data, dan verifikasi data. Adapun tahapan model Miles dan Huberman dalam sugiyono (2014:9299) adalah sebagai berikut:

1) Reduksi Data

Reduksi data merupakan usaha penyederhanaan data dengan cara memilih data dan memusatkannya pada pusat masalah dalam segi akuntabilitas, transparansi dan efektivitas dalam pengelolaan dana BOS.

2) Penyajian Data

Penyajian data merupakan kumpulan informasi yang telah tersusun sehingga membuat peneliti dapat melakukan penarikan kesimpulan dan tindakan dari informasi yang telah didapatkan dalam proses penelitian.

3) Verifikasi data

Verifikasi merupakan kegiatan terakhir yang dilakukan dalam menganalisis data dengan memverifikasi kesesuaian data. Verifikasi data dalam penelitian ini dengan menggunakan Permendikbud Nomor 26 Tahun 2017 untuk melihat kesesuaian data yang didapatkan.

\section{Hasil dan Pembahasan}

\section{Gambaran Umum Objek Penelitian}

Peneliti menyusun pedoman dokumentasi, dengan rincian dokumen yang terdiri dari profil sekolah, sejarah berdirinya sekolah, visi, misi dan 
tujuan sekolah, sarana dan prasarana, data tenaga pendidik dan kependidikan, data peserta didik, RKAS, laporan pertanggungjawaban dana BOS, pembukuan BOS, dan dokumen lain yang relevan seperti buku kas umum, buku bank, dan rekening koran yang dapat dilihat pada lampiran 5, yang bertujuan untuk memudahkan peneliti dalam pengumpulan data mengenai gambaran umum objek penelitian. Hasil Dokumentasi tersebut dapat dilihat bahwa semua sekolah yang menjadi objek penelitian ini telah melakukan penyusunan anggaran yang sesuai dengan peraturan pemerintah yaitu tentang standar nasional pendidikan sebagaimana telah dijelaskan dalam Peraturan Pemerintah No.32 Tahun 2013 Tentang Nasional pendidikan.

SMP Negeri 3 dan SMP Islam YPUI Kota Banda Aceh telah melalukan pencairan dana BOS dengan ketentuan-ketentuan yang telah ditetapkan oleh pemerintah. Pencairan dana terhadap dana BOS tersebut telah dijelaskan oleh narasumber terhadap peneliti yaitu bendahara dana BOS sekolah. Bendahara BOS di SMP Negeri 3 Banda Aceh menjelaskan bahwa mekanisme pencairan dana BOS ke sekolah dengan cara sekolah harus menunjukkan semua buktibukti fisik beserta dokumen-dokumen terkait seperti adanya buku rekening sekolah, pencairan dana BOS hanya dapat diambil oleh kepala sekolah atau bendahara sekolah dengan bukti giro juga harus dilampirkan tanda tangan kepala sekolah dan juga bendahara sekolah beserta laporan peserta didik karena bank penyalur akan mengirimkan uang ke sekolah sesuai dengan jumlah data pendidik sebagaimana yang tertuang dalam Permendikbud No.26 Tahun 2017. Dana yang telah dicairkan ke sekolah hanya dapat digunakan sesuai dengan kebutuhan sekolah sebagaimana yang telah disusun dalam RKAS dan dana BOS yang telah cair baru dapat digunakan jika sudah ada kesepakatan dan keputusan bersama antara Tim Manajemen BOS Sekolah dengan dewan guru beserta komite sekolah. Penggunaan dana BOS harus didasarkan pada kebutuhan sekolah, pada SMP Negeri 3 dan SMP Islam YPUI Kota Banda Aceh dana BOS yang telah cair digunakan untuk membiayai 8 standar nasional pendidikan dan untuk kebutuhan sekolah yang telah ditetapkan oleh pemerintah dalam Permendikbud Nomor 26 Tahun 2017 Tentang Petunjuk Teknis Penggunaan dana BOS.
SMP Negeri 3 dan SMP Islam YPUI Kota Banda Aceh dalam proses penyampaian pelaporan dana BOS telah dilaksanakan sesuai dengan pertanggungjawaban keuangan dana BOS, yang dijelaskan bahwa setiap sekolah harus melaporkan pertanggungjawaban terkait dengan hasil laporannya ke pihak terkait, dalam penelitian ini sekolah yang menjadi objek penelitian harus memberikan pertanggungjawaban kepada Dinas Pendidikan Kota Banda Aceh. Secara umum SMP Negeri 3 dan SMP Islam YPUI Kota Banda Aceh harus memberikan laporan yang berkaitan dengan penyaluran, pemanfaatan dana serta pertanggungjawaban keuanagn dan evaluasi.

\section{Pengalokasian Dana BOS dan Rencana Penggunaan Dana BOS}

Anggaran sekolah yang bersumber dari BOS pusat dialokasikan untuk pembayaran dan pembiayaan belanja pegawai seperti belanja modal, honorarium, belanja barang, dan jasa. Terdapat banyak program sekolah yang juga dapat dibiayai oleh BOS seperti pengembangan kompetensi kelulusan, pengemabangan standar isi, pengembangan standar proses, pengembangan pendidik dan tenaga kependidikan, pengemabngan sarana dan prasarana sekolah, pengembangan standar pengelolaan, pengembangan standar pembiayaan, pengembanagan dan implementasi sistem penilaian.

1) Pengalokasian dana BOS dan Rencana Penggunaan dana BOS di SMP Negeri 3 Banda Aceh

Anggaran dana BOS yang didapatkan di SMP Negeri 3 Banda Aceh dialokasikan untuk meningkatkan kualitas sekolah melalui programprogram sekolah. Penggunaan dana BOS pada sekolah juga harus mengacu pada 8 standar BOS. Realisasi penggunaan dana BOS di SMP Negeri 3 Banda Aceh selama satu tahun anggaran yang terdiri dari Triwulan I (Januari-Maret) dengan penerimaan pada tanggal 31 Maret 2017 dengan dana yang diterima pada tahap I senilai $\mathrm{Rp}$ 151.800.000; Triwulan 2 (April-Juni) dengan penerimaan pada tanggal 31 Maret 2017 dengan dana yang diterima pada tahap II senilai Rp 303.600.000; Triwulan III (Juli-September) dengan penerimaan pada tanggal 10 Agustus 2017 dengan jumlah dana yang diterima pada tap III 
senilai Rp 151.800.000; Triwulan IV (OktoberDesember) dengan penerimaan pada Tanggal 23 November 2017 dengan jumlah dana pada tahap IV senilai Rp 151.800.000. Penerimaan selalu habis terpakai untuk pengeluaran demi melancarkan serta memajukan sekolah tersebut. Realisasi penggunaan dana BOS pusat dapat digunakan dalam 8 standar dengan 8 pengembangan.

2) Pengalokasian dana BOS dan rencana Penggunaan dana BOS di SMP Islam YPUI Darul Ulum Banda Aceh

Anggaran dana BOS yang diterima oleh SMP Islam YPUI Darul Ulum Banda Aceh dialokasikan untuk meningkatkan kualitas sekolah melalui program-program sekolah. Penggunaan dana BOS pada SMP Islam YPUI Darul Ulum Banda Aceh juga harus sesuai dengan petunjuk teknis dana BOS tahun 2017. Realisasi penggunaan dana BOS di SMP Islam YPUI Darul Ulum Banda Aceh selama satu tahun anggaran yang terdiri dari Triwulan I (Januari-Maret) dengan penerimaan pada tanggal 31 Maret 2017 dengan dana yang diterima pada tahap I senilai Rp 45.800.000; Triwulan 2 (April-Juni) dengan penerimaan pada tanggal 30 Juni 2017 dengan dana yang diterima pada tahap II senilai Rp 91.600.000; Triwulan III (Juli-September) dengan penerimaan pada tanggal 30 September 2017 dengan jumlah dana yang diterima pada tap III senilai Rp 45.800.000; Triwulan IV (OktoberDesember) dengan penerimaan pada Tanggal 30 Desember 2017 dengan jumlah dana pada tahap IV senilai Rp 45.800.000. Penerimaan selalu habis terpakai untuk pengeluaran demi melancarkan serta memajukan sekolah tersebut. Realisasi penggunaan dana BOS pusat dapat $\begin{array}{lllll}\text { digunakan dalam } & 8 & \text { standar } & \text { dengan } & 8\end{array}$ pengembangan

\section{Hasil Observasi}

Observasi merupakan salah satu dari teknik yang ada pada penelitian kualitatif. Untuk memudahkan peneliti dalam mengumpulkan data dengan teknik observasi, maka peneliti telah menyusun pedoman observasi untuk masing-masing sekolah yang menjadi objek peneltian. Teknik observasi merupakan salah satu alat pengumpulan data dengan cara mengamati sesuatu yang didasarkan pada penglihatan secara fisik oleh peneliti. Yang menjadi pengamatan dalam hal ini adalah melihat apakah SMP Negeri 3 dan SMP Islam YPUI kota Banda Aceh telah menyiapkan laporan format penyusunan RAPBS, format pencairan dana BOS, format perencanaan dana BOS, format penggunaan dana BOS, format pelaporan dana BOS.

SMP Negeri 3 dan SMP Islam YPUI kota Banda Aceh sudah melalukan penyusunan anggaran sesuai dengan Peraturan Pemerintah Nomor 32 Tahun 2013 Tentang Standar Nasional Pendidikan Permendikbud Nomor 101 Tahun 2013 Rencana Kerja Tahunan hendaknya memuat rencana anggaran pendapatan dan belanja satuan pendidikan untuk masa satu tahun. SMP Negeri 3 dan SMP Islam YPUI kota Banda Aceh sudah membuat RKAS/RAPBS yang dibuat pada tahun ajaran baru, RKAS dibuat hanya untuk satu tahun anggaran dengan anggaran pendapatan dan anggaran pengeluaran. SMP Negeri 3 dan SMP Islam YPUI kota Banda Aceh dalam proses perencanaan dana BOS sudah sesuai dengan permendikbud nomor 26 tahun 2017 tentang petunjuk teknis pelaksanaan dana BOS, yang dibuktikan dengan adanya pembuatan RKAS selama masa satu tahun anggaran. Jika ditinjau dari proses penggunaan dana BOS telah digunakan sesuai dengan juknis BOS tahun 2017 dengan 8 standar penggunaan dana BOS. Dalam penggunaan juga harus ada kesepakatan antara tim manajemen BOS di sekolah dengan dewan guru serta komite sekolah. Kesepakatan tersebut didasarkan atas kebutuhan sekolah, khususnya untuk membantu mempercepat pemenuhan standar pelayanan dan standar nasional pendidikan. Dalam proses pelaporan dana BOS telah menggunakan juknis, yang mana dibuktikan dengan adanya laporan pertanggungjawaban yang dilaporkan kepada pihak terkait.

Hasil observasi lainnya yang didapatkan oleh peneliti dengan mewawancarai salah satu Tim BOS tingkat Kabupaten yaitu salah seorang koordinator pengelolaan dana BOS pada Dinas Pendidikan dan Kebudayaan Kota Banda Aceh guna untuk mendapatkan gambaran lebih mengenai bagaimana pengelolaan dana BOS yang terjadi pada SMP-SMP yang ada di Kota Banda Aceh, hasil wawancara menyatakan bahwa kendala selama ini yang terjadi dalam pengelolaan dana BOS pada SMP di Kota 
Banda Aceh adalah tingkat kepedulian dari Tim BOS sekolah itu sendiri belum ada peningkatan yang diharapkan menjadi lebih baik dan untuk kendala yang lainnya hanya masalah mengenai administrasi yang masih bisa diatasi dan tidak ada terjadi penyelewengan atau pelanggaran yang berat sampai penyelesaian melewati jalur hukum.

\section{Analisis Data Penelitian}

Setelah menyusun rencana anggaran dan menyusun penggunaan dana anggaran tersebut, maka sekolah akan mengetahui berapa jumlah keseluruhan dana yang telah terpakai dan sekolah juga dapat melihat setiap pengeluaran sekolah, maka disusunlah rencana dan realisasi anggaran dan pendapatan belanja sekolah. Pada SMP Negeri 3 dan SMP Islam YPUI kota Banda Aceh terjadi perbedaan angka diantara rencana dengan realisasi penggunaannya. Maka dari hasil analisis RKAS di SMP Negeri 3 dan SMP Islam YPUI kota Banda Aceh Banda Aceh jika terjadi hal seperti itu adanya perbedaan antara rencana dengan realisasi maka pihak sekolah bisa memperbaiki RKAS tersebut dengan revisi RKAS, revisi ini diberikan waktu oleh Dinas Pendidikan Kota Banda Aceh sebelum sekolah memberikan laporan pertanggungjawaban kepada instansi terkait.

\section{Pembahasan}

\section{Pengelolaan Dana BOS}

1) Perencanaan Dana BOS

Dalam perencanaan dana BOS di SMP Negeri 3 dan SMP Islam YPUI kota Banda Aceh menyusun RKAS sebagai laporan dalam perencanaan dana BOS tersebut, RKAS yang telah disusun bertujuan agar sekolah mudah dalam merencanakan kerja tahunan dan untuk menetapkan anggaran tahunan yang terdiri dari anggaran pendapatan dan belanja sekolah untuk satu periode anggaran.

Hasil wawancara dari bendahara dana BOS di SMP Negeri 3 Banda Aceh yaitu “...sekolah akan menyusun RKAS untuk melihat apa saja yang akan menjadi titik perhatian dalam mengubah atau memperbaiki sekolah agar bisa menjadi lebih bagus, dan dalam proses penyusunan RKAS, tidak hanya tim manajemen BOS yang berperan berperan disini, kita juga melibatkan guru dan juga pegawai di sekolah untuk penyusunan hingga mempertimbangkan penggunaannya". Pada SMP Islam YPUI Darul Ulum juga memiliki mekanisme yang sama dalam segi perencanaan.

Dengan demikian bahwa dengan penyusunan RKAS yang melibatkan komponen sekolah dan juga tim manajemen sekolah ini telah mecerminkan bahwa sudah adanya transparansi di sekolah yang menjadi objek penelitian seperti yang tertuang dalam UU No.20 Tahun 2003 pasal 48 yang menyatakan bahwa pengelolaan dana pendidikan harus berdasarkan pada prinsip keadilam, efisiensi, transparansi, dan akuntabilitas publik. Dan pihak sekolah juga harus mendapat persetujuan oleh koordinator BOS kota dalam perencanaan dan BOS. Berdasarkan hal ini dapat disimpulkan bahwa pengelolaan dana BOS di SMP Negeri 3 dan SMP Islam YPUI kota Banda Aceh dalam proses perencanaan sudah sangat baik.

\section{2) Pelaksanaan Dana BOS}

Dalam pelaksanaan dana BOS di SMP Negeri 3 dan SMP Islam YPUI kota Banda Aceh sudah sesuai dengan aturan yang berlaku, karena dapat dilihat dari tahap awal pelaksaan mulai dari penyaluran dana BOS, pencairam dana BOS, penggunaan dana BOS, dan pertanggungjawaban keuangan dana BOS. penyaluran dana BOS dilakukan berdasarkan dengan surat usulan yang telah diterima dan telah ditanda tangani oleh kepala sekolah, kemudian surat tersebut akan diajukan ke kantor perbendaharaan negara untuk di proses. Kemudian dari surat tersebut dana BOS akan dialokasikan dari pusat ke kota, kemudian dinas pendidikan kota akan menyalurkan dana BOS tersebut ke masing-masing sekolah melalui rekening sekolah dari bank daerah. Dana yang diterima oleh pihak sekolah bergantung pada jumlah murid di sekolah tersebut.

Pencairan dana BOS dapat dilakukan melalui bank penyalur dari pemerintah daerah ke rekening sekolah. Pencairan dana BOS dilakukan oleh bendahara sekolah dengan pesetujuan kepala sekolah. Dari hasil wawancara dengan responden di sekolah yang menjadi objek penelitian tidak mencairkan semua dana BOS sekaligus, tapi dilakukan secara bertahap dengan pencairan sesuai kebutuhan sekolah tersebut. Menurut ibu Chairani selaku bendahara di SMP Islam YPUI Darul Ulum Banda Aceh menjelaskan “....proses pencairan dana BOS di sekolah pengambilannya hanya bisa dilakukan oleh bendahara sekolah atau kepala sekolah dengan menunjukkan bukti identitas". 
Dana BOS harus sesuai dengan hasil rapat terkait dengan RKAS dalam penggunaanya, jika ada perubahan dalam penggunaan dana BOS, maka pemerintah daerah memberikan waktu revisi RKAS terhadap sekolah. Hal ini dibuktikan dengan hasil wawancara oleh pihak sekolah, yang menjadi informan disini adalah bu Mawarti selaku bendahara di SMP Negeri 3 Banda Aceh, “...jika dana BOS tidak sesuai dengan RKAS yang telah disusun dalam penggunaanya, maka dinas pendidikan kota memberi kesempatan kepada sekolah untuk merevisi RKAS itu, biasanya revisi RKAS dilakukan 2 kali dalam setahun anggaran, berarti 2 triwulan sekali. Untuk penggunaan dana BOS itu sendiri kita memakai 8 standar seperrti pengembangan kompetensi lulusan, pengembangan standar isi, pengembangan standar proses, pengembangan tenaga pendidik dan kependidikan, pengembangan sarana dan prasarana sekolah, pengembangan standar pengelolaan, pengembangan standar pembiayaan, pengembangan dan implementasi sitem penilaian. Buku-buku murid juga kita akan bantu dengan dana BOS, kemudian persiapan try out dan hal lain yang terdapat di pedoman juknis kita akan gunakan untuk sekolah, ya secara umum penggunaan dana BOS seperti itu".

Tetapi pada SMP Islam YPUI Darul Ulum Banda Aceh adanya sedikit perbedaan dalam penggunaan dana BOS, sesuai yang dikatakan oleh ibu Chairani selaku bendahara sekolah “...penggunaan dana BOS harus mengikuti Juknis BOS 2017, tapi untuk pembayaran honor untuk guru berbeda dengan sekolah negeri, pihak sekolah dapat menaikan presentase penggunaan dana BOS untuk pembayaran honorer dari dana BOS sampai 50\% untuk batas maksimalnya", hal ini selaras juga yang dikatakan oleh pihak Dinas Pendidikan dan Kebudayaan Kota Banda Aceh. Dari penjelasan yang telah didapatakan oleh informan membuktikan bahwa sekolah yang sudah menjadi objek penelitian ini telah menggunakan dana BOS sesuai dengan peraturan yang telah diatur.

Pertanggungjawaban keuangan dana BOS diawali dengan adanya pembukuan dana BOS yang dalam pelaksanaa pembukuan ini, tim belanja harus menyertakan bukti transaksi terhadap dana yang telah terpakai, bukti fisik inilah yang menjadi pertanggungjawaban kepada pemerintah daerah terhadap penggunaan dana yang telah disalurkan ke sekolah. Hal ini sesuai dengan hasil wawancara terhadap informan, ibu Chairani selaku bendahara di SMP Islam YPUI Darul Ulum Banda Aceh mengatakan bahwa “...proses pembukuan yang dilakukan sekolah ini harus didasarkan pada bukti transaksi, seperti kwitansi karena nantinya semua pembukuan dan bukti ini akan dibuat dalam Laporan Pertanggungjawaban (LPJ) dana BOS ke dinas pendidikan kota". Kemudian terkait dengan pelaporan yang juga menjadi pertanggungjawaban keuangan, pelaporan penggunaan dana BOS yang dilaporkan untuk pihak internal maupun eksternal dan kemudian akan di publikasikan oleh sekolah terkait dengan pengelolaan dana BOS tersebut. Data terkait dengan pelaporan dana BOS didapatkan melalui wawancara dengan informan yaitu kepala sekolah dan bendahara sekolah serta dengan dokumentasi. Pertannggungjawaban sekolah kepada pemerintah dengan membberikan laporan pengelolaan dana BOS pada tiap akhir periode anggaran. pihak yang diberikan laporan dana BOS adalah dinas pendidikan kota. Seperti yang dikatakan oleh kepala sekolah SMP Islam Darul Ulum Kota Banda Aceh “...sekolah juga menyusun laporan disetiap akhir periode, laporan itu kemudian akan diberikan ke dinas pendidikan kota, pelaporan ini disusun oleh tim manajemen BOS, bendahara BOS yang sangat berperan dalam penyusunan pelaporan ini". Pelaporan yang telah disusun ini sebagai bentuk pertanggungjawaban kepada pemerintah daerah, laporan pertanggungjawaban keuangan BOS diberikan setiap triwulan, semester dan tahunan kepada Dinas Pendidikan Kota Banda Aceh, laporan pertanggungjawaban juga dibantu dengan BKU, buku rekening sekolah, dan semua bukti transaksi terkait dengan pengeluaran dana BOS. dapat disimpulkan bahwa laporan pertanggungjawaban dana BOS sebagai bentuk tanggung jawab sekolah terhadap penggunaan dana BOS yang digunakan untuk program dan kegaiatn sekolah. Sekolah yang menjadi objek penelitian dinilai telah melakukan pertanggungjawaban sesuai dengan aturan yang berlaku, dan sudah menerapkan pengelolaan dana dari segi akuntabilitas.

\section{Akuntabilitas Dalam Pengelolaan Dana BOS}

Akuntabilitas dalam penelitian ini berarti adanya laporan yang akan di pertanggungjawabkan sesuai dengan peraturan yang telah berlaku, sehingga akan 
membuat semua prosedur berjalan sesuai dengan mestinya. Hal ini dapat dilihat dari pengelolaan untuk SMP yang menjadi objek penelitian, SMP Negeri 3 dan SMP Islam YPUI Darul Ulum Kota Banda Aceh telah menyelesaikan laporan pertanggungjawaban disetiap triwulan dan dikirimkan untuk Dinas Pendidikan Kota Banda Aceh, sekolah juga telah menyiapkan pertanggungjawaban keuangan yang sesuai dengan aturan Permendikbud Nomor 26 Tahun 2017 yaitu dari penyusunan pembukuan pengelolaan dana BOS yang terdiri dari beberapa komponen dan pelaporan pengelolaan dana BOS yang terdiri dari beberapa komponen yang telah ditetapkan, hal ini dibuktikan dengan hasil wawancara bersama kepalas sekolah dan bendahara SMP Negeri 3 dan SMP Islam YPUI Darul Ulum Kota Banda Aceh dan didukung dengan hasil observasi dilapangan beserta dokumentasi yang didapatkan.

Berdasarkan hasil penelitian yang didapatkan melalui hasil studi dokumentasi, observasi dan wawancara pada lampiran 4, 5 dan 6, maka akuntabilitas pada SMP Negeri 3 Banda Aceh dan SMP Islam YPUI Darul Ulum Banda Aceh sudah baik dan sudah sesuai dengan aturan yang ada yaitu Permendikbud Nomor 26 Tahun 2017.

\section{Transparansi Dalam Pengelolaan Dana BOS}

Untuk melihat transparansi yang ada di SMP Negeri 3 dan SMP Islam YPUI Darul Ulum Kota Banda Aceh, maka peneliti melakukan metode wawancara dan studi dokumentasi dan observasi langsung dalam mencari informasi yang berkaitan dengan transparansi. Informasi ini peneliti dapatkan langsung dari informan yang langsung terlibat dalam pengelolaan dana BOS, yaitu bendahara sekolah dan wakil kepala sekolah di SMP Negeri 3 Banda Aceh. Dalam pelaksanaan prinsip transparansi pengelolaan dana BOS di SD dikaitkan dengan laporan yang telah dibuat seperti RKAS dan juga laporan rekapitulasi penggunaan dana BOS. Transparansi dalam penelitian ini berarti adanya keterbukaan infromasi terkait dengan keuangan sekolah, yang berupa sumber dananya maupun penggunaan dananya. Beberapa informasi yang telah didapatkan oleh peneliti seperti hasil wawancara dengan informan yaitu bendahara sekolah yang sekaligus bendahara BOS di SMP Negeri 3 Banda Aceh, “...untuk transparansi insyaAllah kita sudah terlaksana dengan baik, dalam hal melibatkan wali murid dan guru dalam penyusunan berbagai keperluan sekolah, misalnya menyiapkan RKAS, disitu semua dapat berpendapat untuk perubahan sekolah selama satu tahun kedepan, kita juga ikut sertakan mereka dalam rapat rutin sekolah terutama dalam pengelolaan dana BOS, warga sekolah juga dapat mengakses informasi terkait dengan dana BOS ini, karena kita sudah menyediakan papan informasi khusus untuk dana-dana yang ada disekolah yang salah satunya itu dana BOS, itu dapat dilihat pada mading yang ada di halaman sekolah".

Peneliti juga menanyakan kepada informan dari kedua objek penelitian yaitu bendahara BOS SMP Negei 3 Banda Aceh dan SMP Islam YPUI Darul Ulum Banda Aceh, apakah website sekolah aktif?, dan jawaban dari kedua objek penelitian yaitu tidak aktif sama sekali karena tidak adanya website sekolah, tetapi kedua objek juga mengatakan bahwa mereka juga sudah menyampaikan laporan mengenai dana BOS secara online ke laman BOS. Menurut peneliti hal ini sangat disayangkan karena sekolah tidak mempunyai inisiatif untuk mengaktifkan website sekolah itu sendiri, karena mereka berfikir bahwa transparansi secara online telah dilakukan sesuai dengan isi Juknis BOS bahwa Tim BOS harus mennyampaikan laporan penggunaan dana BOS ke laman BOS. Seharusnya jika mereka memiliki inisiatif sendiri untuk mengaktifkan website sekolah, mereka dapat menikmati manfaat yang sangat banyak, mereka bisa melakukan transparansi dana BOS pada website dan juga mereka bisa lebih membuat sekolah dikenal lebih dalam oleh masyarakat.

Dengan adanya hasil infromasi terhadap informan diatas, maka dapat disimpulkan bahwa SMP Negeri 3 Banda Aceh sudah cukup melakukan transparansi terhadap dana BOS. Tetapi untuk SMP Islam YPUI Darul Ulum Banda Aceh masih belum bisa dikatakan transparansi karena masih ada faktorfaktor yang belum untuk memenuhi transparansi yang belum mereka lakukan.

\section{Efektivitas Dalam Pengelolaan Dana BOS}

Efektivitas dalam penelitian ini berarti adanya kesesuaian antara rencana dengan realisasi yang menunjukkan bahwa pelaksanaan dan pengelolaan dana BOS sudah berjalan sesuai dengan peraturan yang berlaku. Efektivitas dana BOS juga sangat penting dalam proses pengelolaan, seperti hasil 
wawancara dengan informan kepala sekolah di SMP Negeri 3 Banda Aceh “...pengelolaan dalam penggunaan dana BOS sudah efektif, namun ketepatan waktunya masih kurang seperti waktu penyaluran dan juga waktu pengumpulan laporan pertanggungjawaban, karena yang menyusun laporanlaporan ini guru, guru juga harus mengajar 24 jam, jadi sangat sedikit waktu yang tersisa untuk menyusun laporan-laporan yang diperlukan terkait dengan dana BOS, sehingga sekolah selalu telat dalam memberikan hasil laporan pertanggungjawaban ke dinas pendidikan kota". Dapat disimpulkan bahwa kurangnya efektivitas terdapat dalam pengelolaan memberikan laporan pertanggungjawaban yang tidak tepat waktu, tetapi jika efektivitas ditinjau dari penggunaan sudah efektif. Hal ini bisa dibuktikan bahwa penggunaan dana BOS sudah efektif berdasarkan hasil studi dokumentasi dan observasi langsung untuk membantu keselarasan dengan informasi dari hasil wawancara, dapat dipastikan bahwa penggunaan dana BOS sudah efektif yaitu kejelasan dan tujuan yang ingin dicapai dalam perencanaan dana BOS sudah sesuai dengan pengelolaan dan penggunaan yang terjadi, dapat dibuktikan dengan adanya RKAS perencanaan penggunaan dana BOS selama 1 tahun sesuai dengan Laporan Realisasi penggunaan dana BOS, bagaimana dana BOS digunakan sesuai dengan standar yang ditentukan dalam Permendikbud Nomor 26 Tahun 2017. Hal ini dapat dilihat pada Lampiran 7 Hasil Data Penelitian.

Penyaluran dana BOS dari pemerintah ke sekolah juga sering terjadi keterlambatan, hal ini sering terjadi pada awal triwulan dana BOS diberikan biasanya pada akhir triwulan pertama. Sesuai dengan informasi yang didapatkan oleh bendahara SMP Islam YPUI Darul Ulum Banda Aceh “...penyaluran dana BOS pada awal triwulan sering terjadi keterlambatan". Hal ini juga yang membuat dan BOS menjadi kurang efektif yang dapat menyebabkan rencana yang telah disusun untuk program dana BOS akan terganggu karena keterlambatan penyaluran dana BOS.

\section{Kesimpulan, Keterbatasan dan Saran Kesimpulan}

Berdasarkan hasil analisis data dan pembahasan pada BAB IV maka dapat diambil kesimpulan sebagai berikut:

1) Akuntabilitas pengelolaan dana BOS di SMP Negeri 3 dan SMP Islam YPUI Darul Ulum
Banda Aceh sudah akuntabel dapat dilihat dari bentuk laporan pertanggungjawaban yang telah disusun sesuai dengan Permendikbud Nomor 26 Tahun 2017, laporan pertanggungjawaban tersebut juga diberikan kepada pemerintah daerah, seperti Dinas Pendidikan Kota Banda Aceh.

2) Transparansi pengelolaan dana BOS di SMP Negeri 3 Banda Aceh Banda Aceh sudah terlihat transparan, dibuktikan dengan adanya kelengkapan dan keterbukaan informasi terkait dengan penerimaan dana BOS, penggunaan dana BOS serta berbagai informasi yang tersedia terkait dengan pengelolaan dana BOS, dan juga keikutsertaan warga sekolah dalam mengelola dana BOS, juga keterbukaan informasi terkait penyusunan RKAS, tetapi untuk SMP Islam YPUI Darul Ulum Banda Aceh masih belum dikatakan transparansi, karena laporan pertanggungjawaban kepada masyarakat sekolah dan masyakat luar sekolah tidak ditempelkan pada mading sekolah yang seharusnya itu dilakukan. Transparansi lainnya di SMP Islam YPUI Darul Ulum Banda Aceh sudah dilakukan sama hal seperti pada SMP Negeri 3 Banda Aceh hanya saja pada bagian keterbukaan kepada masyarakat luar sekolah yang belum dilakukan dengan baik.

3) Efektivitas pengelolaan dana BOS dinilai sudah cukup efektif karena adanya informasi yang tersedia sudah dapat dipenuhi oleh kebutuhan masyarakat dan pencapaian tujuan dari pengeluaran dana BOS juga sudah baik dan sesuai dengan rencana kerja yang telah dibuat yaitu RKAS, hanya saja ada beberapa hal yang masih tidak sesuai harapan yaitu masalah keterlambatan dalam penyaluran dana BOS.

\section{Keterbatasan}

Dalam penelitian ini memiliki keterbatasan, terdapat beberapa kesulitan yang penulis alami dalam melakukan penelitian ini, yaitu sebagai berikut:

1) Sekolah sangat sulit memberikan informasi terkait dengan data keuangan sekolah.

2) Data yang didapatkan dalam penelitian ini masih terbatas, karena belum melibatkan warga sekolah karena pihak sekolah sulit memberikan informasi mengenai siapa wali murid yang terlibat dalam pengelolaan dana BOS. Sehingga data yang didapatkan bersifat subjektif. 
3) Peneliti belum melakukan pencocokan data pembukuan dengan kelengkapan bukti-bukti transaksi.

\section{Saran}

Berdasarkan paparan diatas maka terdapat saran yang dapat dijadikan pertimbangan adalah sebagai berikut:

1) Bagi Pemerintah

Sebaiknya pemerintah dapat mengatasi keterlambatan dana BOS yang terjadi di sekolah, dan dapat memperhatikan jumlah kinerja pegawai.

2) Bagi sekolah

Diharapkan sekolah dapat meningkatkan efektivitas dengan memberikan laporan yang tepat waktu kepada dinas pendidikan kota. Pada SMP Islam YPUI Banda Aceh diharapkan dapat memperbaiki dari segi akuntabilitas dan transparansi.

3) Bagi peneliti lain

Bagi peneliti selanjutnya yang akan melakukan penelitian terkait pengelolaan dana BOS dapat mengambil masalah dengan bagaimana pastisipasi masyarakat terhadap dana BOS, bagaimana pengadaan barang yang menggunakan dana BOS dan bagaimana perbandingan antara sekolah Negeri dan Swasta dari semua aspek untuk mengukur sekolah mana yang memiliki tingkat pengelolaan dana BOS yang baik.

\section{Daftar Pustaka}

Andi, M., AR, M., Usman, N. (2015). Efektivitas Penggunaan Dana Bantuan Operasional Sekolah pada Madrasah Ibtidaiyah Swasta di Kabupaten Pidie, 1, 53-63.

Anggraini, R. D. (2013). Transparansi , Partisipasi , dan Akuntabilitas Pengelolaan Anggaran Dana BOS Dalam Program RKAS di SDN Pacarkeling VIII Surabaya, 1, 201-208.

Bastian, I. (2014). Modul 1: Lingkup Akuntansi Sektor Publik. Eks14207

CNN Indonesia. (2016). Penyimpangan Dana Bos Terjadi Karena Pelanggaran Regulasi. Melalui <https://www.cnnindonesia.com/nasional/2016 0521103521-20-132385/penyimpangan-danabos-terjadi-karena-pelanggaran-regulasi> .
Fitri, A. (2014). Pengelolaan Dana Bantuan Operasional Sekolah (BOS) Sekolah Dasar Negeri Kecamatan Mandiangin Koto Selayan Kota Bukittinggi. Bahana Manajemen Pendidikan, 2 (1), 33-831.

Ismail, F. (2008). Manajemen Berbasis Sekolah: Solusi Peningkatan Kualitas Pendidikan. Jurnal Igra'1, 5.

Jpnn. (2018). Dana BOS Telat, Kasek Tombok Puluhan Juta. Melalui $<$ https://www.jpnn.com/news/dana-bos-telatkasek-tombok-puluhan-juta?page $=1>$

Kristianten. (2006). Transparansi Anggaran Pemerintah. Jakarta: Rineka Cipta.

Pratiwi, S. N. (2016). Manajemen Berbasis Sekolah dalam Meningkatkan Kualitas Sekolah. Jurnal EduTech, 2 (1).

Republik Indonesia. (1945). Undang-Undang Dasar 1945.

(2003). Undang-Undang Dasar Republik Indonesia Nomor 17 Tahun 2003 tentang Keuangan Negara.

. (2003). Undang-Undang Dasar Republik Indonesia Nomor 20 Tahun 2003 tentang Sistem Pendidikan Nasional.

(2009). Peraturan Menteri Pendidikan Nasional Nomor 69 Tahun 2009 Tentang Pembiayaan Pendidikan.

(2014). Peraturan Pemerintah Nomor 29 Tahun 2014 tentang Sistem Akuntabilitas Kinerja Instansi Pemerintah.

(2017). Peraturan Menteri Pendidikan dan Budaya Nomor 26 Tahun 2017 tentang Petunjuk Teknis Bantuan Operasional Sekolah.

. (2018). Peraturan Menteri Pendidikan dan Budaya Nomor 1 Tahun 2018 tentang Petunjuk Teknis Bantuan Operasional Sekolah.

Serambinews. (2018). Aceh Belum Terima BOS. Melalui

$<$ http://aceh.tribunnews.com/2018/02/26/acehbelum-terima-bos>.

Sekaran, U., Bougie, R. (2016). Research methods for business: A skill building approach. Long Range Planning (Vol. 26).

Siagian, S. P. (1978). Manajemen. Yogyakarta: Liberty.

Silele, E., Sabijono, H., Pusung, R. J. (2017). Evaluasi Pengeloaan Dana Bantuan Operasional Sekolah 
(BOS) (Studi Kasus pada SD Inpres 4 Desa

Akediri Kecamatan Jailolo Kabupaten

Halmahera Barat), EMBA, 5 (2), 1626-1635.

Sugiyono. (2014). Metode Penelitian Pendidikan

Pendekatan Kuantitatif, Kualitatif dan $R \& D$.

Metode Penelitian Pendidikan Pendekatan

Kuantitatif, Kualitatif Dan R\&D.

Sugiyono. (20015). Penelitian Pendidikan,

Pendekatan Kuantitatif, Kualitatif, dan $R \& D$.

Bandung: Alfabeta. 